Isidore Lee MD, Jack Chalon MD, Sivan Ramanathan MD, Sandra Gross Bs, Herman Turndorf MD

\title{
Analgesic properties of meperidine, amitriptyline and phenelzine in mice
}

Sixty three white Swiss Webster mice were divided into seven equal groups. Their tolerance to pain (heat applied so the tail by a test tube containing hot water at a temperature measured by telethermometry) was assessed before and after intraperitoneal injection of $(1)$ physiologic saline; (2) meperidine $14 \mu \mathrm{g}^{-1} \mathrm{~g}^{-1}$; (3) amitriptyline $6 \mu \mathrm{g} \cdot \mathrm{g}^{-1}$ (4) amitripryline $12 \mu \mathrm{g} \cdot \mathrm{g}^{-1}$; (5) phenelzine $1.5 \mu \mathrm{g} \cdot \mathrm{g}^{-t} ;(6)$ phenelzine $3 \mu \mathrm{g} \cdot \mathrm{g}^{-1}$; and (7) amitriptyline $6 \mu \mathrm{g} \cdot \mathrm{g}^{-t}$ plus phenelzine $1.5 \mu \mathrm{g} \cdot \mathrm{g}^{-1}$. All postinjection tests were conducted 45 and 90 minutes after administration, and repeated 24 hours later. No significant difference in pain threshold was noted in any pre-injection test or in any test conducted with physiologic saline. By 90 minutes post-injection, all groups receiving drugs developed increased tolerance to pain. Mice which had received phenelzine plus amitriptyline. or either dose of phenelzine were more tolerant to pain for up to 24 hours than mice which had received physiologic saline. The most marked increases in tolerance to pain were seen with I.5 $\mu \mathrm{g} \cdot \mathrm{g}^{-1}$ and $3 \mu \mathrm{g} \cdot \mathrm{g}^{-1}$ of phenelzine and phenelzine plus amitriptyline. However, phenelzine was more effective and had a longer-lasting effect than either dose of amitriptyline, or meperidine. The combination of phenelzine plus amitriptyline was no more effective than phenelzine alone.

\section{Key words}

PAIN: experimental, acute; ANALGESICS: meperidine; ATARACTICs: antidepressants, tricyclic; amitriptyline, phenelzine.

From the Department of Anesthesiology, New York University Medical Center.

Address correspondence to: J. Chalon MD, Dept. of Anesthesiology, New York University Medical Center, 550 First Avenue, New York, N.Y. 10016, U.S.A.
Tricyclic antidepressants have been used clinically for the management of pain. ${ }^{1,2}$ It has been suggested that monoamine oxidase inhibitors might be used for the same purpose ${ }^{3}$ Furthermore, the combination of a tricyclic antidepressant with a monoamine oxidase inhibitor has been reported to be effective in the treatment of depression ${ }^{4,5}$ without causing additive toxic effects. ${ }^{5}$ We have wondered whether monoamine oxidase inhibitors alone or in combination with tricyclic antidepressants could relieve acute pain. Therefore, we have studied the tolerance to pain of mice, held by the tail on a metal grid, before and after the administration of meperidine, amitriptyline (Elavil), phenelzine (Nardil), or both amitriptyline and phenelzine. A test tube containing water, warmed gradually, was repeatedly applied to their tails. The temperature at which the animals gave a sudden characteristic tug when they felt pain was noted.

\section{Methods}

Sixty-three white Webster mice weighing $34 \pm 1 \mathrm{~g}$ and aged three months, were used in the study. They were divided into seven equal groups. The first or control group (C) received $1 \mathrm{ml}$ physiologic saline intraperitoneally. The second group (M) received intraperitoneal meperidine $14 \mu \mathrm{g} \cdot \mathrm{g}^{-1}$ in $1 \mathrm{ml}$ physiologic saline. The third and fourth groups (A1 and A2) received amitriptyline $6 \mu \mathrm{g} \cdot \mathrm{g}^{-1}$ or $12 \mu \mathrm{g} \cdot \mathrm{g}^{-1}$ respectively in $1 \mathrm{ml}$ physiologic saline intraperitoneally. The fifth and sixth groups (P1 and P2) received phenelzine $1.5 \mu \mathrm{g} \cdot \mathrm{g}^{-1}$ or $3 \mu \mathrm{g} \cdot \mathrm{g}^{-1}$ intraperitoneally, each in $1 \mathrm{ml}$ physiologic saline. The seventh group (Al + Pl) received amitriptyline $6 \mu \mathrm{g} \cdot \mathrm{g}^{-1}$ plus phenelzine $1.5 \mu \mathrm{g} \cdot \mathrm{g}^{-1}$ intraperitoneally, each in $0.5 \mathrm{ml}$ physiologic saline. All were tested, pre- and post-injection, for their reaction to pain. A test tube containing water and thermistor probe inserted through its corked upper 


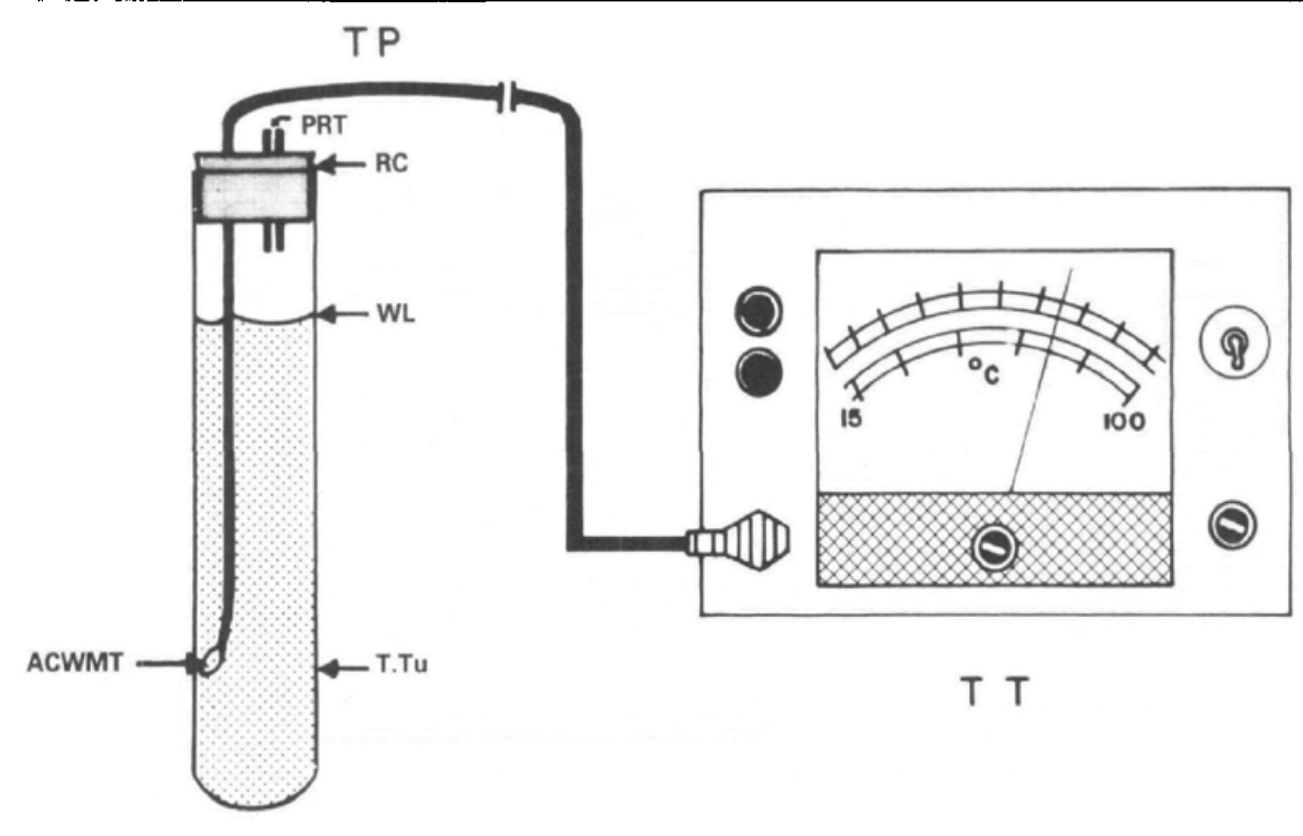

FIGURE System used to test musine sensitivity to heat. T. Tu = test tube filled with warm water, ACWMT = aren in contact with mouse tail, $\mathrm{WL}=$ water level, $\mathrm{RC}=$ nubber cork, $\mathrm{PRT}=$ pressure relief tube, $\mathrm{TP}=$ themistor probe, $\mathrm{TT}=$ tclethctmometer reading from $15^{\circ} \mathrm{C}$ to $100^{\circ} \mathrm{C}$.

end and connected to a telethermometer reading from $15^{\circ} \mathrm{C}$ to $100^{\circ} \mathrm{C}$ (YSI Electronics, model 43, Fisher Scientific Co., Springfield, N.J.), was heated and applied to the sides of the tails of the mice (Figure). The tip of the thermistor probe rested against the inner wall of that portion of the test tube which was applied to the tails of the mice. The cork contained a pressure relief metal tube. The test tube was heated by immersion in hot water until the telethermometer read $60^{\circ} \mathrm{C}$. Care was taken not to prolong contact between the mouse tail and the test tube for over one second. Further experiments were conducted at temperatures elevated incrementally to $72^{\circ} \mathrm{C}$, by $3^{\circ} \mathrm{C}$, after which temperature was elevated gradually by $1^{\circ} \mathrm{C}$ at a time. Each mouse was placed on a metal grid and held by the tip of the tail allowing freedom of movement. When the mouse gave a sudden characteristic tug within 0.5 to 1 second after application of the heated test tube, it was considered to have felt pain (pain reflex) ${ }^{6}$ All tails were examined for sores at the end of each experiment and after 24 hours. Humane standards equal to those described by the American Physiological Society were employed.

Results were expressed as mean temperature at which each of nine mice per group reacted to heat ( \pm 1 SEM). Statistical significance for paired and unpaired data was assessed by Student's t test. Values of $\mathrm{P}<0.05$ were considered significant.

\section{Results}

There was no statistically significant difference between the mean temperatures at which any group reacted to pain before injection (Table I). There also was no significant difference between pre- and post-injection temperatures at which group C mice reacted to pain. Group $M$ mice reacted to pain at a higher temperature 45 and 90 minutes after injection than before injection $(P<0.001$ in both instances) but not 24 hours later. Mice in groups A 1 and $A 2$ also reacted to pain at a higher temperature 45 and 90 minutes after injection than before injection $(P<0.01$ for both groups at 45 minutes post-injection and $\mathrm{P}<0.001$ for group $\mathrm{Al}$ and $\mathrm{P}<$ 
TABLE 1 Pain reaction times

\begin{tabular}{|c|c|c|c|c|c|c|c|}
\hline \multirow{2}{*}{$\begin{array}{l}\text { Group } \\
\text { studied }\end{array}$} & \multirow{2}{*}{$\begin{array}{l}\text { Before } \\
\text { injection }\end{array}$} & \multicolumn{6}{|c|}{ Time after injection } \\
\hline & & $P$ & 45 minutes & $P$ & 90 minutes & $P$ & 24 hours \\
\hline C & $77.2 \pm 2.0$ & NS & $76.7 \pm 2.0$ & NS & $77.9 \pm 2.0$ & NS & $76.1 \pm 1.8$ \\
\hline $\mathbf{M}$ & $74.4 \pm 0.4$ & $<0.001$ & $86.4 \pm 0.5 \ddagger$ & $<0.001$ & $86.1 \pm 0.5 \ddagger$ & NS & $75.2 \pm 0.6$ \\
\hline Al & $75.1 \pm 1.6$ & $<0.01$ & $82.8 \pm 1.1 \dagger$ & $<0.001$ & $83.8 \pm 1.3^{*}$ & NS & $77.8 \pm 1.7$ \\
\hline $\mathrm{A} 2$ & $74.1 \pm 1.5$ & $<0.01$ & $81.0 \pm 1.3^{*}$ & $<0.01$ & $83.1 \pm 1.2 *$ & NS & $77.7 \pm 1.8$ \\
\hline Pl & $75.7 \pm 0.5$ & $<0.001$ & $86.7 \pm 0.7 \$$ & $<0.001$ & $87.3 \pm 0.7 \ddagger$ & $<0.001$ & $87.8 \pm 1.8 \ddagger$ \\
\hline $\mathrm{P} 2$ & $75.3 \pm 1.4$ & $<0.001$ & $86.9 \pm 0.7+$ & $<0.001$ & 38.4 上0.9‡ & $<0.001$ & $89.3 \pm 1.4 \ddagger$ \\
\hline$A 1+P l$ & $74.8 \pm 0.7$ & $<0.001$ & $85.8 \pm 2.0 \neq$ & $<0.001$ & $88.6 \pm 1.3 \neq$ & $<0.001$ & $89.6 \pm 2.0 \neq$ \\
\hline
\end{tabular}

Values are mean temperatures in degrees Celcius ( \pm 1 SEM) al which mice start to react to pain. Paired comparisons: comparisons between pre-injection and post-injection temperatures at which mice started to react to pain in relation to time elapsed since the injection. $\mathrm{P}$ values are indicated in the table. Unpraired comparisons; comparişons berween graups studied and controls before injection, and 45 minutes, 90 minutes and 24 hours after injection. Slatistical significances are indicated by symbols: ${ }^{*}=P<$ $0.05, \div=\mathrm{P}<0.01, \ddagger=\mathrm{P}<0.001 \mathrm{C}=$ controls, $\mathrm{M}=$ meperidine $14 \mu \mathrm{g} \cdot \mathrm{g}^{-1}, \mathrm{Al}=$ amitriptyline $6 \mu \mathrm{g} \cdot \mathrm{g}^{-1}, \mathrm{~A} 2=$ amitriptyline $12 \mu \mathrm{g} \cdot \mathrm{g}^{-1}, \mathrm{P} 1=$ phenelzine $1.5 \mu \mathrm{g} \cdot \mathrm{g}^{-1}, \mathrm{P} 2=$ phenelzine $3 \mu \mathrm{g} \cdot \mathrm{g}^{-1}, \mathrm{Al}+\mathrm{Pl}=$ amitriptyline $6 \mu \mathrm{g} \cdot \mathrm{g}^{-1}$ plus phenelzine $\mathrm{L} .5 \mu \mathrm{g} \cdot \mathrm{g}^{-1}$. $\mathrm{N}=9 \mathrm{in}$ each group, $\mathrm{NS}=$ not significant.

0.01 for group A2 90 minutes post-injection) but not 24 hours !ater. Groups P1, P2 and $\mathrm{A} 1+\mathrm{P} 1$ all reacted to pain at a higher temperature in all post-injection periods than during pre-injection tests ( $\mathrm{P}<0.00 \mathrm{I}$ at all time intervals tested). Group $M$ mice reacted to pain at a higher temperature than grouj $C, 45$ and 90 minutes after injection $(P<$ 0.001 in both instances). Groups $\mathrm{A} 1$ and $\mathrm{A} 2$ reacted to pain at a higher temperature than group $C, 45$ and 90 minutes post-injection $(P<0.1$ and $P<0.05$ at 45 minutes and $P<0.05$ for both groups at 90 minutes) but not 24 hours later. Groups P1, P2 and $\mathrm{Al}+\mathrm{Pl}$ reacted to pain at a higher temperature than group $\mathrm{C}$ during all post-injection test periods $(\mathrm{P}<$ 0.001 in each instance, except group $\mathrm{A} 1+\mathrm{Pl}$ at 45 minutes when $P$ was less than 0.01).

Ta.ble II shows that phenelzine (group P1) had a more effective analgesic action than amitriptyline (group Al), $(P<0.01$ at 45 minutes and $P<0.05$ at 90 minutes, and $P<0.00124$ hours post-injection). Amilriptyline (group A1) was less effective in the relie: of pain than meperidine, only at the 45 -minute post-injection test. There was no additive effect when amitriptyline was added to phenelzine. The tail of the mice never suffered more than a first degree burn, lasting less than 30 minutes. None cried out during the application of heat.

\section{Discussion}

We were careful to avoid prolonged contact between the heated test tube and the side of the tails of the mice. This was to prevent thermal injury to the caudal artery, an axial structure, which, if cauterized, would have caused severe trauma.

The delay between the application of heat and the reflex reaction suggests that the latter was due to pain rather than heat. This is because heat does not elicit noxious stimuli unless it is high enough to cause pain.

The monoamine oxidase inhibitor (phenelzine) and the tricyclic depressant (amitriptyline) relcived acute pain in mice. Our results show that phenelzine is most effective in the treatment of acute pain and that its effect lasts longer than that of amitriptyline. Spiker and Pugh ${ }^{5}$ noted that there were no additive side effects when a monoamine oxidase inhibitor was used in combination with tricyclic antidepressants. The phenelzine-amitriptyline combination which we used in our study seems to verify this assertion. There were no dose-effect relationships when phenelzine or amitriptyline were used. This suggests that the lower dose of these drugs was sufficient to produce maximal effects (Table I). However, phenelzine was always more effective than amitriptyline (Table II) and had a more prolonged duration of action (Table I). Thus, the lower dose of phenelzine seems to be the drug of choice for the prolonged elevation of pain threshold. The higher doses correspond to twice the normally used daily clinical doses $\left(3 \mathrm{mg} \cdot \mathrm{kg}^{-1}\right.$ for phenelzine and $12 \mathrm{mg} \mathrm{kg}^{-1}$ for amitriptyline). These higher doses were tested in our study to 
TABLE II Summary of comparisons

\begin{tabular}{|c|c|c|c|}
\hline \multirow[b]{2}{*}{ Group studied } & \multicolumn{3}{|c|}{ Time afler injection } \\
\hline & 45 minitres & 90 minutes & 24 hours \\
\hline $\begin{array}{l}\text { Phanelzine } 1.5 \mu \mathrm{g} \cdot \mathrm{g}^{-1} \\
\text { vs } \\
\text { amitriptyline } 6 \mu \mathrm{g} \cdot \mathrm{g}^{-1}\end{array}$ & $\begin{array}{l}86.7 \pm 0.7 \\
\uparrow \\
82.8 \pm 1.1\end{array}$ & $\begin{array}{l}87.3 \pm 0.7 \\
* \\
83.8 \pm 1.3\end{array}$ & $\begin{array}{l}87.8 \pm 1.8 \\
+ \\
77.8 \pm 1.7\end{array}$ \\
\hline $\begin{array}{l}\text { Phenelzine } 3 \mu \mathrm{g} \cdot \mathrm{g}^{-1} \\
\text { vs } \\
\text { amitriptyline } 12 \mu \mathrm{g} \cdot \mathrm{g}^{-1}\end{array}$ & $\begin{array}{l}86.9 \pm 0.7 \\
\dagger \\
81.0 \pm 1.3\end{array}$ & $\begin{array}{l}88.4=0.9 \\
\dagger \\
83.1 \pm 1.2\end{array}$ & $\begin{array}{l}89.3 \pm 1.4 \\
\ddagger \\
77.7 \pm 1.8\end{array}$ \\
\hline $\begin{array}{l}\text { Phenelzine } 1.5 \mu \mathrm{g} \cdot \mathrm{g}^{-1} \\
\text { vs } \\
\text { meperidine } 14 \mu \mathrm{g} \cdot \mathrm{g}^{-1}\end{array}$ & $\begin{array}{l}86.7 \pm 0.7 \\
\text { NS } \\
86.4 \pm 0.5\end{array}$ & $\begin{array}{l}87.3=0.7 \\
\text { NS } \\
86.1=0.5\end{array}$ & $\begin{array}{l}87.8 \pm 1.8 \\
\ddagger \\
75.2 \pm 0.6\end{array}$ \\
\hline $\begin{array}{l}\text { Amitriptyline } 6 \mu \mathrm{g} \cdot \mathrm{g}^{-1} \\
\text { vs } \\
\text { meperidine } 14 \mu \mathrm{g} \cdot \mathrm{g}^{-1}\end{array}$ & $\begin{array}{l}82.8 \pm 1.1 \\
* \\
86.4 \pm 0.5\end{array}$ & $\begin{array}{l}83.8=1.3 \\
\mathrm{NS} \\
86.1=0.5\end{array}$ & $\begin{array}{l}77.8 \pm 1.7 \\
\text { NS } \\
75.2 \pm 0.6\end{array}$ \\
\hline $\begin{array}{l}\text { Phenelzine } 1.5 \mu \mathrm{g} \cdot \mathrm{g}^{-1} \\
\text { vs } \\
\text { amitriptyline } 6 \mu \mathrm{g} \cdot \mathrm{g}^{-1} \\
\text { plus } \\
\text { phenelzine } 1.5 \mu \mathrm{g} \cdot \mathrm{g}^{-1}\end{array}$ & $\begin{array}{l}86.7 \pm 0.7 \\
\text { NS }\end{array}$ & $\begin{array}{l}87.3=0.7 \\
\text { NS }\end{array}$ & $\begin{array}{l}87.8 \pm 1.8 \\
\text { NS }\end{array}$ \\
\hline
\end{tabular}

determine if mice were more tolerant to phenelzine and amitriptyline than man. The dose of meperidine we used corresponds to $1,000 \mathrm{mg}$ for a $70 \mathrm{~kg}$ man. Mice are well known to be far more tolerant to narcotics than humans. ${ }^{7}$ They can be given over ten times the nomal clinical dose and remain awake and breathing adequately.

As is well known, phenelzine (Nardil) being a monoamine oxidase inhibitor must be used with a restricted diet. Subjects taking this drug must avoid foods containing tyramine (a pressor amine). Because pain increases the secretion of catecholamines, which are catabolized slowly in the presence of phenelzine, the combination of these pressor amines might produce a dangerous elevation in blood pressure.

\section{Acknowledgement}

The authors wish to thank Dr Martin L. Black, of the Warner-Lambert Co. (Pharmaceutical Research Division) for providing pure crystalline phenelzine sulfate.

\section{References}

1 Dalessio DJ. Chronic pain syndromes and disordered cortical inhibition: effects of tricyclic compounds. Dis Nerv Syst 1967; 28: 325-8.

2 Moore $D P$. Treatment of chronic pain with tricyclic antidepressants. South Med J 1980; 73: 1585-6.

3 Raskin DE. MAO inhibitors in chronic pain and depression. J Clin Psychiatry; 43: 122.

4 White $K$, Pistole T, Boyd JL. Combined monaamine oxidase inhibitor-tricyclic antidepressant treatment: a pilot study. Am J Psychiatry 1980; 137: 1422-5.

5 Spiker DJ, Pugh DD. Combining tricyclic and monoamine oxidase antidepressants. Arch Gen Psychiatry 1976; 33: 828-30.

6 Wolf $H G$. On the nature of pain. Physiol Rev. 1947; 27: 167-99.

7 Way EL, Loh $H H$, Shew FH. Simultaneous quantitative assessment of morphine tolerance and physical dependence. J Pharmacol Exper Therap 1969; 167: 1-8. 
Résumé

Soixante-trois souris blanches Webster furent divisées en sept groupes égaux. Leur tolérance à la douleur (chaleur appliquée d la queue par une éprouvette chauffée au bainmarie et dont la température du contenu d'eau était mesurée par téléthermométrie) fut mesurée avant et après l'injection intrapéritonéale: 1) de solution saline physiologique; 2) de mépéridine $14 \mu \mathrm{g} \cdot \mathrm{g}^{-1}$; 3) d'amitriptyline $6 \mu \mathrm{g} \cdot \mathrm{g}^{-1}$; 4) d'amitriptyline $12 \mu \mathrm{g} \cdot \mathrm{g}^{-1}$; 5) de phênelzine $1.5 \mu g \cdot g^{-1}$; 6) de phénelzine $3 \mu g \cdot g^{-1}$; et 7) d'amitriptyline $6 \mu g^{\cdot} g^{-1}$ et de phénelzine $1.5 \mu \mathrm{g} \cdot \mathrm{g}^{-t}$. Tous les essais suivant les injections furent mesurés 45 et 90 minutes après l'administration des solutions intrapéritonéales et 24 heures plus tard. On ne trouva pas de différence significative du seuil de la douleur avant et après les injections de solution saline physiologique. A partir de 90 minutes après l'injection des drogues on nota une augmentation de la tolérance à la douleur chez tous les groupes. Les souris ayant reçu de la phénelzine et de l'amitriptyline ou une des deux doses de phénelzine tolérèrent mieux la douleur que celles ayant reçu de la solution saline physiologique. Cette tolerance dura jusqu'd 24 heures dans certains cas. On nota l'aug. mentation la plus marquée de la tolérance da la douleur avec l'emploi de $1.5 \mu \mathrm{g} \cdot \mathrm{g}^{\mu \prime}$ et $3 \mu \mathrm{g} \cdot \mathrm{g}^{-1}$ de phénelzine de même qu'avec une combinaison de phénelzine et $d$ ' amitriptyline. La phénelzine fut plus efficace cependant er eur un effet plus prolongé que les doses d' amitriptyline el de méperidine. L'emploi d' une combinaison de phérelzine et d'amitriptyline ne fut pas plus efficace que l'emploi de phénelzine seule. 